\title{
DEVELOPING EMPATHIC SENSITIVITY IN YOUNGER CHILDREN
}

\author{
SANDRA KWAŚNIEWSKA-PASZTA ${ }^{1}$ \\ ${ }^{1}$ University of Warsaw, Faculty of Education, ul. Mokotowska 16/20, 00-651 Warsaw. ORCID: \\ 0000-0001-5164-5763, Email: sandrakwasniewska511@gmail.com
}

ABSTRACT: The article presents a review of theoretical concepts on empathic sensitivity. The text demonstrates correlations between empathy and moral development and presents empathy in children and its conditions. The article is also aimed at pointing to the significance of empathy in human relations, and it introduces several factors which influence bringing up children to have empathy. Moreover, it presents the methods of working with children aimed at developing their empathic sensitivity. These include, among others, drama, working with literary texts and art techniques. KEYWORDS: empathy, children, upbringing, emotions, moral development, early childhood education

\section{INTRODUCTION}

$\mathbf{F}$ mpathy is considered to be the fundamental mechanism of human interaction and communication (Rembowski 1989b). It enables accurate interpretation of other people, acts of communication, personality, making it possible to anticipate human behaviours. It also constitutes one of the most important factors determining personality development (Tomczuk 2004: 105). The already mentioned emphatic sensitivity is associated with the ability to recognise, name and express emotions, as well as with 
readiness to help others (Hoffman 2006: 31).

Most often, empathy has been related to the cognitive and emotional sphere. In the context of the former, empathy has been treated as the process of responding emotionally to other people's emotions. On the other hand, in terms of the cognitive sphere, empathy has been perceived as an understanding of other people. Over time, empathy has started to emerge as a complementary, emotional and cognitive process. Some researchers also identify the behavioural component of empathy, which includes, among other things, communicating of the perceived state of the other person (Tomczuk 2004:106).

This article presents a review of emphatic sensitivity concepts by such researchers as Theodor Lipps, Mark H. Davis, or Martin L. Hoffman. The theoretical models of empathy selected and analysed, reveal its multifaceted nature. The article presents the difference between empathy and compassion, as well as the origin of the concept of empathy. Moreover, correlations between empathy and moral development have been pointed out. The article discusses the conditioning of childhood empathy and attempts to emphasize the need for its development in children, proposing specific methods of working with them in this regard. The described factors that influence empathy development have been complemented with selected results of scientific research, conducted, among others, by Jean Decety and Christian Keysers. This article is addressed in particular to educators, namely, junior-grade teachers who would like to develop empathic sensitivity in their students.

One of the important components of globalisation processes is migrations, which contribute to changes in European countries and communities' political, cultural and social structure (Markowska-Manista and Pasamonik 2017:7). An increase in the number of migrants coming to Poland results in a growing number of migrant children attending Polish kindergartens and schools (Barwiński 2016:149). To ensure these pupils' successful integration and education, teachers have to have both cultural and social competencies, including empathy (Białek 2015:12). Research conducted by Morgan has shown that emphatic teachers are more eager to express their feelings and create an atmosphere of openness and trust in the classroom (Morgan 1983).

Moreover, the $21^{\text {st }}$ century is characterised by an intensive pace of life, technological progress, urbanisation and an increase in the prestige of science and technology (Strumińska-Doktór 2008). Like in the second half of the $19^{\text {th }}$ century, scientific discoveries are made, and many inventions emerge (Piechota 2019). The global range of the Internet has influenced the way we communicate. Research conducted by Sherry Turkle has shown that the modern generation of teenagers is emotionally addicted to smartphones (Jędrysik 2015). The boundary between the real and virtual world has been blurred, exerting a destructive impact on the emotional development of young people, who tend to avoid direct contact, are unable to hold conversations, while being online makes them feel tired, lost and frustrated (Jędrysik 2015). It should also be added that the multitude of problems and stress faced by people often lead to treating altruistic behaviours as something of minor importance. At the same time, the individual empathy levels tend to decrease (Wilczek 2002:17).

Many researchers interested in empathy state that it determines the strong, emo- 
tional bonds between people (Kliś 2012:152). In scientific literature, it has been pointed out that empathy conditions altruistic behaviours (Aronfreed 1970) are strictly correlated with willingness to cooperate and influence the process of controlling and inhibiting aggressive behaviours (Feshbach 1969). Moreover, empathy is coexistent with the tendency to solve conflicts and the sense of responsibility for self and others (Kaliopuska 1992). It also facilitates conveying of information in the course of human communication (Kliś 2012:152).

In the light of the listed functions of empathy and challenges of the modern world, including, among other things, the development of ICT tools and the Internet (Kwasek 2018:210). As well as clashing of social and cultural differences, and attitudes such as intolerance, lack of knowledge of others, ignorance, or helplessness (Markowska-Manista 2016:322). Empathic sensitivity becomes of particular relevance. Undoubtedly, the development of empathy should start at an early age. It is the parents who are mostly responsible for the upbringing process. They are the child's first and most important teachers. From the start of their child's life, they should develop their pro-social attitudes (Więcławska 2018:46). Teachers also play an important role in the process of development of childhood empathy. By creating specific educative situations, they may cause significant changes in how the child perceives the world of people and feelings. A number of methods are used to develop childhood empathy, which will be described in the further part of the article. These include working with literal texts, art techniques, drama, as well as inductive reasoning.

\section{EMPATHY AND COMPASSION}

The term "empathy" comes from the German word Einfuhlung. For the first time, the term appeared in German aestheticism. Initially, it was understood as the ability of the observer to identify themselves to some extent with the object being observed - usually, it was a physical object which influenced the way a person experienced beauty. Over time, the term was introduced into the psychological context and used in research on optical illusions. Eventually, it was on processes that make it possible to get to know other people. The English term empathy was established as a translation of the term Einfuhlung. It was believed that the mechanism which makes us deal with empathy is "an internal imitation of the person or object being observed" (Gulin 1994:36). This process is known today as motor mimicry. It means that while witnessing another person's emotional state, we receive certain hints which induce us to internal mimicry of the signs of the state observed. One example is the tensing of muscles when looking at someone who is under stress, which ultimately leads to similar - albeit weaker - reactions experienced by the observer. How can we then distinguish between compassion and empathy? Undoubtedly, compassion was understood as a much more passive phenomenon - it was focused on how the observer got to feel the same as others or what could make him feel moved by someone else's feelings. On the other hand, empathy seemed to be more active and focused on another person's feelings (Gulin 1994:36). 


\section{SELECTED CONCEPTS OF EMPATHY - LIPPS, DAVIS, HOFFMAN AND OTHERS}

Theodor Lipps made empathy the foundation of almost all possible emotional and social processes. He distinguished between positive and negative empathy. The former is strictly related to similar emotional states of the observer and the observed, which translates mainly to pro-social activity. The second type of empathy is related to various emotional states of the empathiser and the object resulting from empathy. In other words, positive empathy is nothing but the fulfilment of the need to empathize, which brings us internal satisfaction. On the other hand, negative empathy is about a lack of fulfilment of this need, which, in turn, leads to a sense of distress (Gulin 1994:36). An example here may be a situation when one person is joyful and the other - sorrowful. These opposite states make it impossible to fully empathise, resulting in a sense of distress in one of the subjects (Gulin 1997:30).

The concept of empathy by Lipps enables to distinguish six types:

(a) Mood empathy - the subject attributes emotions to a work of art being observed; the ultimate effect of human interaction with a work of art is a specific experience, which is brought down to the reflection of mood;

(b) Aesthetic empathy - related to mood empathy and pertaining to the aesthetic experiencing beauty;

(c) Retrospective empathy - based on a memory which is triggered by a reminder;

(d) Apperceptive empathy - based on visual and auditory apperception;

(e) Intellectual empathy - serving as a developmental foundation for speech, which mirrors the development of intellect;

(f) Ethical empathy - related to altruistic acts which serve as a basis for the development of societies (Gulin 1997:30).

Summing up, it should be stated that Theodor Lipps perceives empathy not only as the core psychological, but also sociological mechanism (Gulin 1994:36).

On the other hand, according to Mark H. Davis, the introduction of the term 'empathy' has resulted in the phenomenon of perception of emotional states being given a different, more active character. More emphasis has been put on the so-called intentional cognitive processes. Much earlier, affect sharing was usually perceived as a passive learning process or functioning of a biological mechanism. It is also worth noting that research on empathy, initiated by Theodor Lipps and Edward Titchener, has clearly defined the observer as acting consciously and, additionally, making an effort to go beyond the self, into the sphere space of the burden of human experience. In this manner, the active process of "empathising" has undoubtedly become an issue that interested many researchers, who started to focus on it in their works. In his book on empathy (Davis 1994). Has proposed a research model in which the starting point is the definition of empathy as a set of theoretical constructions related to an individual's responses to experiences of others, connected to processes taking place in 
the observer and their effects. The model assumes that the so-called typical empathic "episode" occurs as follows: the observer meets the observed, resulting in a response of the observer. The response may be affective, cognitive, or behavioural. This model has led to a breakthrough in the perception of empathy. It encompasses many phenomena and serves as an attempt to provide a broad, comprehensive perspective of the concept of empathy, which is undoubtedly a great achievement.

For Martin L. Hoffman (2006:38). One of the modern theoreticians of empathy, the most significant condition of an empathic response, is the involvement of emotional processes, making a given person feel emotions that fit another person's situation better than their own. The processes that trigger empathy very often trigger the same feelings in the observer as those experienced by the victim, although - according to the researcher - this does not always have to be the case. An example here is empathic anger, for instance, by witnessing an attack, while the victim feels sorrow or disappointment. Hoffman has often underlined that to him; it is much more important to define empathy not in terms of the result but in terms of processes that serve as the basis for the correlation between the feelings of the observed and the observer. Moreover, empathy was understood as emotional learning to empathise with another person and has been considered an emotional response triggered by emotions by another person, which results in a much better understanding of various emotional states or complex social behaviours. Empathy has also been defined as the emotional communication link between people, or an emotional response to perceptible and at the same time emotional experiences of others. In this case, the observer responds emphatically because they are aware of the other person going through or experiencing specific emotions (Rembowski 1989a:48). According to another theory, empathy is an emotional-cognitive response in the first place, which constitutes communication between people regarding their current feelings (Wilczek-Różyczka 2002:12).

We can distinguish the following four components of empathy (Wilczek-Różyczka 2002:12).

(a) the emotional component - the ability to subjectively feel the emotional state, feelings or internal emotions of others;

(b) the moral component - an internal belief that makes us ready to use empathy in practice;

(c) the cognitive component - the ability to recognise/understand the feelings of others and the ability to objectify these;

(d) the behavioural component - a response that shows an understanding of the point of view of another individual.

Another significant component of empathy is related to communication and social skills. The factors listed should not be analysed separately, as all processes are correlated and complement one another (Baron-Cohen 2014).

In this place, worth noting is also the Altmann and Roth model, presenting the four stages of the empathic process. 


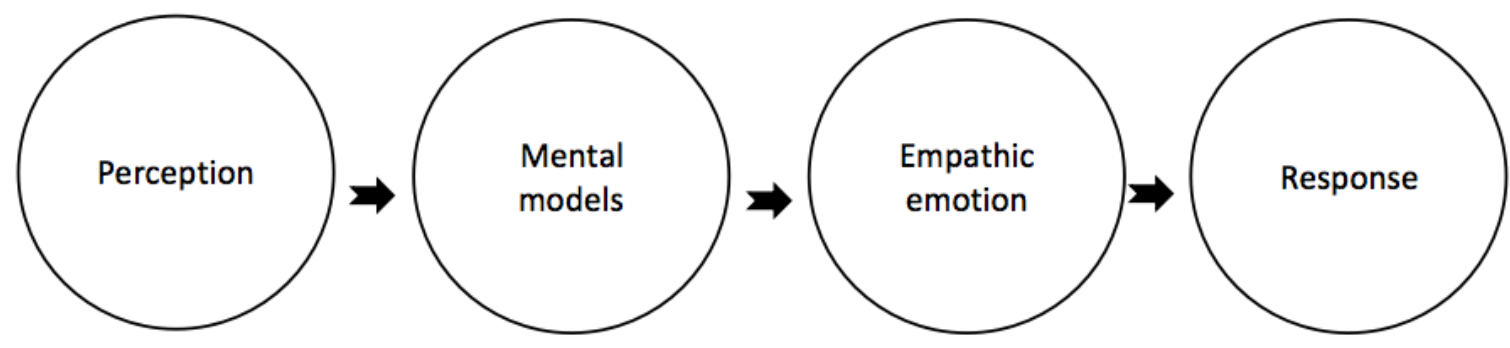

Figure 1. Phases of the process-based model of empathy by Altmann and Roth (2013: 171).

The first stage of perception refers to emotional sensitivity, perceptive readiness and attention processes. Depending on the level of sensitivity of a given person, a specific response of another individual may be considered relevant or not by this person. Some people may fail to notice the emotional expression of another individual or remain unmoved by it. To sum up the above, the observer may, but does not have to, get to the next stage of the empathic process (Ciechomski 2018:70).

The next phase is the development of mental models by the observer. In this stage, we refer to the interpretation of emotional arousal triggered by the earlier observation. Knowledge, experience, and cognitive skills, play an important role in this phase (Ciechomski 2018:71).

Interactions between emotional and cognitive processes influence a specific empathic emotion, which is motivating. Depending on the course of the previous processes, this emotion may direct a given person towards assistance, coordinated responses or withdrawal (Ciechomski 2018:71).

The empathic processes described in the above model always result from the observer-actor interaction. The last phase of the process is the empathic response, that is, the response of the individual, conditioned by the course of the previous stages, as well as the skills and abilities of the observer (Ciechomski 2018:71).

Summing up the above, it should be stated that the most frequently presented concept of empathic sensitivity pertains to the attempt of empathising with another person or of taking their role.

\section{EMPATHY AND MORAL DEVELOPMENT}

The development of empathic sensitivity in children is related to moral development. This is because empathy makes it possible to reach full moral autonomy. Moral upbringing refers not only to the acquisition of the ability to tell good from evil but also to shape moral behaviours. According to Mieczysław Łobocki, moral education should focus, in particular, on sensitising others to harm and strengthening their sense of dignity. All moral norms should be based not only on externally acquired principles but also on internal choice. This is particularly important in older children above ten 
years of age (Łobocki 2002). Moreover, another significant component of moral education is "referring to autonomic emotional (empathic) processes that develop in the course of social interactions" (Łobocki 2002).

On the other hand, life stories of empathic persons, analysed by Kristen Monroe, show that these individuals considered their own stance to be an obligation. One of the methods that shape pro-social attitudes in children is based on rewarding children for such behaviours that shape their sense of identity as a person helping others. This is very well illustrated by a situation in which the adult addresses the child, saying, "you did this, because you are a person who helps others" (Ciechomski 2018).

Jean Piaget, a Swiss psychologist, understood moral development as a process in which human personality undergoes changes that lead to the emergence of a specific system of values and the associated rules of conduct. This process takes place on two levels: cognitive, related to reasoning and moral assessments, and behavioural, related to all moral acts (Birch 2005:165). On the cognitive level, we refer to reasoning and moral assessments. On the other hand, all moral acts belong to the behavioural level (Birch 2005:165).

Jean Piaget differentiates between two stages of moral development - heteronomous morality (moral realism) and autonomous morality (moral relativism). During the first stage, the child considers all principles to be unquestionable, sacred and unchanging. Everything that is good or evil is perceived as either black or white, and activities are assessed from the perspective of potential material benefits and not motives or intentions of individuals (Birch 2005:165).

The second stage commences when the child is 7 or 8 years old. All principles are perceived by the child as being established, maintained through a contract between members of a given community. All moral assessments and whether something is good or bad is based on motives behind specific acts and related material benefits (Birch 2005:165). Moreover, getting from the first stage to the second is warranted by growing up, that is, cognitive development of the child and all social situations experienced (Birch 2005:165). The first stage is influenced by egocentrism, that is, the inability to perceive the situation from the perspective of others and the fact that children are dependent on adults (Skorupka 1969:157).

The Swiss researcher studied empathy; however, it should be noted that in his works, the term closest to empathy was decentration, that is, the ability to go beyond "self" and to notice the concept of "you". It is the ability to place oneself in the situation of another person and realise their emotional states. Jean Piaget stated that it is not possible to differentiate between an individual or emotional processes in decentration, as these processes constitute a certain whole. Another concept that this renowned psychologist refers to is sympathy, identified with empathy for others, which is present in the world of children. According to Piaget, the child's behaviour towards others "reveals - from the first days of life - the tendency to sympathise and display emotional responses, which can clearly be seen as the raw material which serves as a foundation for further moral behaviours" (Rembowski 1989a:29). Although the Swiss scientist did not write directly about empathy, his reflections on sympathising, egocentrism, and decentration undoubtedly served as the starting point for future psy- 
chologists, dealing mainly with developmental psychology, who used and developed this knowledge (Rembowski 1989a:30).

Lawrence Kohlberg formulated the theory of moral reasoning. According to this American psychologist, moral development takes place on three levels. These are (Birch 2005:167).

(1) Pre-conventional morality - level typical of children aged 2 to 7 . The child acts to avoid punishment and to achieve what they consider to be pleasant. Kohlberg recognises two stages here. The first one is the orientation of obedience and punishment, in which egocentrism is typical. The consequences of the act determine whether it is good or bad. The child does not consider the needs, interests or perspectives of others (Łobocki 2006: 59).

The second stage is egotistic orientation, which is characterised by moral relativism. An act that can be considered good at the stage of egotistic orientation is aimed at own good and not that of others. The needs of others are considered important only if their acts are beneficial to the individual's good (Birch 2005:167).

(2) Conventional morality - typical of children aged 7 to 11 . At this level, the individual fits into social conventions and adapts their own desires to them. Two levels of conventional morality are distinguished. The first one is the good boy/girl orientation. Moral behaviour is the one that meets the expectations of family or other groups. Therefore, socially accepted behaviours are valued and repeated. The second stage is the law-and-order orientation. At this stage, the child is convinced that the rules of social life must be followed as much as possible, and respect for authorities emerges. Moreover, not only the motives for action are considered, but also the present external standards (Birch 2005:167).

(3) Post-conventional memory - this level is displayed by girls and boys around 12 years of age. The individual becomes morally autonomous, able to compare their own moral principles with those of other people. Post-conventional morality consists of two stages. The first one is the social contract orientation - whatever is good or right depends on the majority's opinion. The basis for morality is the defence of human rights. The social system is important as it warrants the defence of these rights (Vasta, Haith \& Miller 1995: 485). The second stage is that of the orientation of universal ethical rules - the individual follows the ethical standards in which they believe. When the law comes into conflict with these principles, the individual remains faithful to them (Birch 2005:167).

Developing this theory of moral development, Lawrence Kohlberg followed the views of Jean Piaget on the stages of moral development (Łobocki 2006:59). Experiments have confirmed Lawrence Kohlberg's theory. It has been proven that the moral development of children takes place in stages (Vasta et al. 1995:494).

Summing up, it should be said that moral development consists of a gradual transition from the stage of heteronomy to moral autonomy (Buksik 1997:165). In the theory of Kohlberg and Piaget, moral development results from improving cognitive skills and repeating encounters with specific problems of moral nature (Olek-Redlarska 2015). Moral development, as described above and its course, is relevant in developing empathy, which contributes to the achievement of full moral autonomy. Therefore, 
both the sphere of education and upbringing should emphasise the development of empathic sensitivity in children.

\section{DEVELOPMENT OF EMPATHIC SENSITIVITY IN CHILDREN}

Biological processes partially influence the development of empathy. People are by nature sensitive to other human beings. This trait is displayed in a primitive form in childhood, although children are unable to differentiate between their feelings and those of others. In cognitive development, they learn to understand the feelings of others better and to identify their causes. First empathic responses are displayed as early as 2 to 3 (Vasta et al. 1995:503). Full development of empathy takes place later in childhood, making it possible to transfer empathic responses to more general groups, e.g., of the poor.

The child's experience also influences the development of empathic sensitivity. Acceleration of empathy development may occur if the parents teach the children to recognize their own emotions and those of others. Explaining the impact of the child's inappropriate behaviour on the feelings of others may also contribute to the development of empathy. Moreover, verbalisation by the parents of their feelings results in increased attention of the children to these processes. This leads to their better understanding (Vasta et al. 1995:503).

An empathic child, apart from recognising the emotions of others, lives through them, although not so intensively. While observing a person in need, they feel emotional uneasiness. It is possible to get rid of this uneasiness by empathising or providing assistance. If pro-social behaviours lead to positive feelings in others, such as joy or happiness, an empathic child may also feel them (Vasta et al. 1995:503).

In early childhood, the perspective of "self" takes precedence over that of "others". Therefore, children's altruistic behaviours are rarely displayed and have to be triggered and strengthened (Klus-Stańska \& Szczepska-Pustkowska 2009:378).

Discussing the development of emphatic sensitivity in children, it is impossible to disregard the model of empathy developed by Martin L. Hoffman. According to the American psychologist, in the first year of their life, a child feels global empathy. No sense of "self" characterises this period in the child. Any suffering of any other person leads to an undifferentiated response of distress. At this stage, the child cannot tell who is experiencing suffering: them or perhaps somebody else. M.L. Hoffman refers to this as empathic suffering. By the end of their first year of life, children become able to understand that they are individuals, separate from other people. They start to develop psychical representations of themselves and others, and separateness of suffering experienced by them or by others becomes increasingly recognisable (Davis 1994:56). The second level of empathy is referred to as egocentric empathy. The child achieves this level more or less at the end of the first year of life. They realise that others are human beings separate from them but are still unaware that they may differ from them, also in terms of internal feelings. At this stage, children often respond to the suffering of others, proposing ineffective assistance, which they consider to be things that make them feel better. The researcher also points to the so-called empa- 
thised suffering, which is characterised most by the expression of compassion for the observed. The child has two different motivations, strictly related to the perception of the suffering of others. The first motivation is the purely egotistic need to reduce their sense of distress. In contrast, the other motivation is related to the need to reduce distress felt by others, which is associated with helping (Davis 1994:57). At the egocentric empathy level, the attempt to provide assistance may often fail, which changes as the child develops.

The penultimate stage is referred to as empathy concerning the feelings of others. It is characteristic of children aged 2 to 3, and lasts until late childhood. As the child acquires a better sense of social orientation at this stage, they gradually assume roles. It means they can place themselves in the position of a person being observed in a given situation and making this effort results in an affective response similar to that of the observed. At this stage, the child can properly assess the type of assistance that would be most suitable for someone in a given situation (Davis 1994:58).

The last level of empathy is known as empathy in response to someone's overall situation. This level is achieved in late childhood or in the early adolescence period. Over time, humans become more aware of others as those who have a certain past and specific traits. All this results in taking into account the aspects of the life of the observed person (Davis 1994:58).

Awareness of the course of development of empathic sensitivity in children, presented above, is significant in the upbringing process, both in terms of the parent-child and the teacher-child relationship. Knowledge about phenomena described in the above subchapter may be used to understand the motives of children's behaviours.

\section{CONDITIONS OF EMPATHY}

In terms of development, empathy is a process strictly related to ontogenesis. On the other hand, it is undoubtedly a specific trait, developing individually in the social context. The development of empathy depends on several factors. Some of these include:

(a) features of the empathising subject

(b) family environment of the subject

(c) conditions of living of the subject

(d) the situation and time of the process (Wilczek-Różyczka 2002:16).

In terms of the first factor, it should be said that people inherit only affective components of empathy - the tendency to experience empathic care and personal distress (Davis 1994:369). Individual differences in empathising are determined by emotional sensitivity and responsiveness, which, on the other hand, are strictly related to inherited temperamental characteristics. Simultaneously, it should be noted that temperament does not condition the ability to assume a perspective (Czerniawska and Dolata 2005:125). Moreover, a correlation has been discovered between gender and the level of empathy. Research conducted (Wilczek-Różyczka 2002:16) has shown that 
girls are more empathic than boys. Similar differences have been noted in women and men (Wilczek-Różyczka 2002:16). In the context of the factor being discussed, worth mentioning is also research by Jean Decety, who has shown that people characterised by high psychopathy levels are characterised by abnormal neuron connections and neural activity in areas related to empathy (Denworth 2018:68). Psychopaths understand what other people feel but are characterised by lack of empathic care (Skorupka 2019:46). On the other hand, researchers conducted by neuropsychologist Christian Keysers using magnetic resonance on persons with anti-social personality have proven that psychopaths are capable of empathy, but, unlike people with a shaped personality, they must employ a conscious intention to display it. According to the researcher, this discovery may be of great relevance in developing a therapy that would automatise empathy in psychopathic persons (Keysers 2011).

The development of empathy is also influenced by history of the child-parent relationship. The level of attachment of infants to their parents and early childhood experiences influence the transmission of feelings and expectations to social relations at further stages of life (Czerniawska and Dolata 2005:125). In environments characterised by social pathologies, conflicts, or inappropriate attitudes of the parents, the level of empathy will be inhibited. Empathic communication between the child and their environment results in internalisation of values, behaviours and patterns. It is also of great relevance for developing the child's personality, free of any neurotic or psychosomatic traits. Any delay in communication development leads to emotional problems (Wilczek-Różyczka 2002:17).

The conditions of living of the individual also shape the mode of development of their empathic sensitivity. The modern world is undoubtedly characterised by an intensive pace of living, technological development, urbanisation etc. Life, mostly in big cities, leads to indifference to one another. This, among other things, is a consequence of the scale of problems and stress which cause individuals preoccupied with their own matters to remain far from the development of empathic sensitivity or altruistic behaviours (Wilczek-Różyczka 2002:17).

The last of the listed factors that influence the development of empathy is the situation and time in which it takes place. The process of empathy is strong whenever one person perceives the other as similar to them, e.g., in terms of age, gender or race. A higher level of empathy is related to the object being a close friend or relative. However, not all studies have confirmed this thesis (Wilczek-Różyczka 2002:17). In terms of the factor being discussed, one may refer to the research conducted by C. Daniel Bateson and J. Darley, which has shown that placing people in a situation that requires them to hurry significantly reduces their willingness to help others. Decades later, C.D. Bateson established that those who empathised with others helped more frequently than those feeling distressed due to the suffering of others (Denworth 2018:71).

\section{EMPATHY IN HUMAN RELATIONS AND THE NEED TO DEVELOP IT IN CHILDREN}

Empathy is necessary to achieve good relationships with others. In the context of the 
already mentioned friendly human relationships, the following traits of character turn out to be of utmost importance:

(a) the ability to anticipate the possible situations in the course of the interaction,

(b) awareness of the impression one makes on the other partner/ interlocutor,

(c) ability to assess the motives of the partner's actions properly,

(d) ability to analyse own motives and consequences of actions chosen,

(e) the capability of social perception focuses on events that may be of interpersonal significance (Wilczek-Różyczka 2002:20).

One of the dimensions of task-based empathy is the activity of an individual for the benefit of society. Human relations based on empathy lead to such feelings as friendliness, tolerance, hospitality. Therefore, it is very important to develop empathy from the youngest age. According to psychologists, there are three groups of factors that can improve one's ability to perceive a given situation from the perspective of another person. These are:

(a) inductive reasoning, which consists in the fact that the student is presented with positive or negative consequences of their acts to others,

(b) training - based on seeing all possible modes of action of persons participating in a given event,

(c) treating the child empathically, relationships with parents based on partnership, lack of any punishment or experiences which might make the child feel rejected (Łobocki 1998:126).

In upbringing, it is necessary to provide the child with as many proper experiences as possible, as children are shaped by experience. One of the proposals is to conduct lessons on the development of empathy. It would be good if the students got to know themselves in two spheres: "myself" and "myself-others". The first sphere should provide children with knowledge of their own emotions, while the second should focus on relations with others (Minkiewicz-Najtkowska 2003:115). However, it is necessary to keep in mind that the development of empathy in children requires patience from both teachers and parents, as it is known that successes in upbringing never come immediately (Łobocki 1998:159).

The parents also play an important role in the development of empathy. They should serve as role models of pro-social behaviours for their children. Their task is also to express compassion and empathy in relation to other people in an open, natural manner. The parents may support the development of empathy in children by allowing them to experience various emotions and playing with children to assume various roles (Hoffman 2006: 31).

According to Maciej Ciechomski, upbringing for empathy should be analysed holis- 
tically. In his opinion, factors that contribute to the development of empathy through upbringing include:

- emotional sensitivity, which determines the strength of emotional excitation under the influence of emotional triggers. We experience the emotions of others as we observe their responses. The intensity of these feelings depends on the sensitivity of the observer. Empathic sensitivity is necessary to take over the emotional states of others and to show compassion to other people. The shaping of empathic sensitivity undoubtedly depends on early experiences encountered at home (Ciechomski 2018:70).

- the ability to imagine another person's perspective, which refers to the understanding of the way of thinking of the other person, also allowing to understand the given situation better. This is mainly a cognitive process, which nevertheless triggers affective processes;

- knowledge of emotions, which is one of the important tasks of emotional education of children. The ability to name emotions makes it possible to define the feelings of another person better and gain a better insight into one's experiences. It is very important to present the functions of emotions to children, that is, why we need them and the potential consequences of emotions felt (Ciechomski 2018:68).

- communication skills, which are useful in the last phase of emotional interaction. A full emotional reaction requires assuming of another person's perspective and showing emotional support to them. Communication skills in empathy refer mainly to the communication of emotions, verbalisation of one's feelings and needs. Exercises aimed at developing these skills contribute to shaping assertive attitudes in children, giving them the right to feel and communicate their feelings (Ciechomski 2018:80).

- group norms are related to supporting the development of empathy. These are norms that support children in open communication. Worth noting is the fact that it is not about developing codes of conduct for groups but about the component of this group's culture or atmosphere. The child should be sure that speaking about their emotions is natural. Thus, the atmosphere in the group should be friendly, open and supportive. Another type of norms that support empathy is norms related to the cultivation of responsibility for others, friendliness or care (Ciechomski 2018:88).

- personal courage, which refers to speaking and acting following one's beliefs regardless of the consequences. It also serves as a factor connecting the internal dispositions, situational conditions and behaviours of a given person in various social situations. It should be noted that internal dispositions of an individual, that is, for instance, empathic sensitivity and assuming of perspectives of others, are not a sufficient prerequisite to provide someone with assistance. In many 
cases, people lack the courage necessary to join an action actively. The decision to withdraw may be influenced by fear, a sense of guilt, lack of belief in own abilities, fear of being rejected by the group, etc. (Ciechomski 2018:83).

In the context of moral courage, described above, worth noting is the Heroic Imagination Project (HIP) (Markowska-Manista 2014). It is an educational project based on the newest discoveries of social psychology and aspects of the social capability model of Lynne Henderson, Ph. D., which make it possible to oppose any negative situational and social impacts in the context of the educational sphere of pupils and students. This programme, developed by Professor Phillip Zimbardo, aims to shape pro-social behaviours among children, adolescents, and adults. The HIP project affirms the socalled everyday heroism. According to the concept of Zimbardo, it is important for every person to be aware that they can become heroes, as they can make significant and lasting changes in their everyday life environment. We can distinguish two components of preparation for heroic acts. The first one pertains to pro-social practices based on a change of thinking and behaviour. The second refers to situational awareness, or a thorough analysis of the situation, which is based on acquired knowledge and ability to deduce. Thus, people become more aware and ready to act responsibly (Markowska-Manista 2014:56). The program provides knowledge, proper tools, strategies, as well as exercises helpful in overcoming passiveness which prevents pro-social activity. Examples are exercises based on expressing own opinions, discussing, role-playing (Markowska-Manista and Zimbardo 2014:58).

In an interview conducted by Urszula Markowska-Manista, Ph. D., Professor Zimbardo stated that the evaluative research conducted showed that the HIP programme exerted a positive influence on students' attitudes, including social involvement (Markowska-Manista 2014:63).

The HIP project aims to shape pro-social attitudes, which are also particularly relevant in the context of developing childhood empathy. Undoubtedly, upbringing should include strengthening of the child's courage to make them able, among other things, to help others selflessly.

The work methods that enable broadening of the range of experience of the child in the context of the above factors that contribute to upbringing to develop empathy include, for example (Łobocki 1998:159).

The circle of feelings - the teacher and the students sit together in a circle. It is aimed at encouraging the children to express their feelings and to listen carefully to others. It also contributes to visual and emotional contact (Hoffman 2006).

Completing of sentences - this method allows for the development of the ability to express oneself and communicate in a group. The children get to know each other by completing each other's sentences while noticing their similarities and differences (Hoffman 2006).

Drama - a form of play which is based on assuming of fictional roles; it enables children to experience themselves in a given context, helping them understand the attitudes and emotions of others; it helps shape such social skills as empa- 
thy, ability to listen, change of perspective, openness and respect for rights of others; it allows for learning through action and activation of emotions that fit the situation; drama classes make children pay attention to the needs and feelings of others; the drama techniques include: switching of roles, making it easier to understand the feelings and thoughts of a given person in a given situation, since in playing their role, the child feels and interacts with other children, and after they have withdrawn from the role, they can analyse their experiences and conclude (Szafrańska 2006:264).

Working with literary texts - tales and stories make it possible for children to learn to identify emotions, as well as to differentiate between good and evil; fairy tales provide children with new experiences and develop their personality; thanks to them, children are motivated to fantasise, solve specific problems, as well as think analytically; many stories have motives which are very close to children and their sensitivity, as they match their problems and provide the space to express themselves; fairy tales and stories play an important role in education through play in the context of the environment of kindergarten children; thanks to such literary texts, as well as play and mobility games, children learn communication, values, cooperation, they gain knowledge of the world and develop their imagination; the examples of play modes which can be used while working with stories are mobility games, artistic plays, role playing, discussions, pantomime (Markowska-Manista 2019:46).

Art techniques - these include drawing, painting, sculpture or graphics; free artistic expression through cutting out shapes, modelling clay, drawing, painting allows the child to spontaneously depict their experiences as well as their knowledge of the world; use of specific art techniques allows the child to release emotional stress, to intensify cognitive processes or human interactions, as well as to develop their interests and creative abilities; the course of work using art techniques is strictly related to emergence of a problem situation, drawing, discussion of the content of drawings and use of the pieces of art created (Bogucka and Turaj 2004:119).

Based on the factors listed above, which influence the development of childhood empathy, and the associated methods of working with children, it can be said that education through play performs a significant role in this context. Moreover, analysis of various conflict situations that emerge between children and pointing out to children the experiences and emotions of others in various everyday situations is a natural way to shape pro-social attitudes.

\section{SUMMARY}

This article aimed to point out the importance of developing empathy in children and reviewing and analysing theoretical issues related to the term empathy. To sum up, one must state that empathy is an elementary social concept. Empathy develops grad- 
ually from the moment of birth and with the support of adults present in the child's environment. The most intense development of empathic abilities takes place in early childhood. Empathic experiences of an individual are influenced by, among others, developmental and social contexts, interactions of cognitive and emotional processes, etc. (Ciechomski 2018). There is no doubt that the correct development of empathy is conditioned by the correct socialization process of the individual, during which moral orientation plays a crucial role (Szczepańska-Pabiszczak 2015).

Analysis of the origin of the concept of empathy has shown that what distinguishes it from compassion is its active nature, which makes it focus on the experiences of others. On the other hand, compassion is more passive and refers to analysis of the process of reception of the emotional states of others by the observer (Gulin 1994:36).

On the other hand, selected concepts of empathic sensitivity of such researchers as Lipps, Hoffman or Davis have revealed its multifaceted nature. The most frequently used definition of empathy referred to empathising with another person and assuming their role.

Moreover, analyses of the correlation between empathy and moral development have shown that empathy allows for the achievement of full moral autonomy. Analysis of moral development models of Piaget and Kohlberg has proven that moral development takes place in stages, as a consequence of two factors - the improving cognitive skills and repeated encounters with specific moral problems (Olek-Redlarska 2015). Given the above, one must emphasize the importance of both education and upbringing, which should consider the development of empathic sensitivity in children.

Concerning the described development of empathic sensitivity in children, it should be stated that it is influenced by biological processes and the child's experiences. Analysis of the course of development of empathy in children according to Hoffman's model has distinguished its four levels: global, egocentric, related to one's feelings and response to someone's general situation. According to this model, the development of empathy takes place in stages, as in the case of the analysed moral development. Here, it must be noted that the knowledge of the process of empathic sensitivity development in children is fundamental from the perspective of upbringing. This refers to both the teacher-child and the parent-child relationship. Furthermore, the knowledge of the discussed contents may contribute to a better understanding of children's behaviour motivations. This knowledge could also be shared during various types of workshops for parents or in on-line webinars.

In the context of conditioning the empathy, several factors have been distinguished and discussed, such as traits of the empathising subject, their family situation, living conditions and the situation and time of the empathy process (Wilczek-Różyczka 2002:16). Analysis of each of the factors has been complemented with selected social research by such researchers as Jean Decety, Christian Keysers, Wilczek-Różyczka, or Czerniawska. Their research is interesting from the point of view of the importance of the development of empathy in children, especially in today's world with its technologically progressive nature, which contributes to the fact that children spend more and more time in front of computers or tablets, which, in turn, has a negative impact on their wellbeing, correct development and health, including the emotional sphere. 
Among the presented studies, there are those that point out the significance of childhood experiences for empathic communication between the child and its environment. It impacts both the internalization of specific values, patterns and behaviour, and on the sphere of feelings and social relations in later life. The environment in which various conflicts or improper parental attitudes emerge and social pathology results in suppression of the empathy level in a child (Wilczek-Różyczka 2002:17).

Empathy in human interactions and developing it in children is the final issue discussed in this chapter. The development of empathy in children is of utmost importance, as it influences, e.g., the quality of human relationships. Empathy enables proper recognition of emotions - our own, as well as of those who surround us. Thus, a proper reading of the emotions of others contributes to better social relations. Empathy inhibits aggressive behaviours and exerts significant influence on compliance with moral norms that warrant better social functioning. The role of the school and the parents in the development of empathy has been underlined. The participation of adults at the stage of early childhood experiences in the caregiver-child relationship is equally important as in later experiences, closely related to proper stimulation of social development of children during kindergarten and school education. Adults who provide positive social experiences simultaneously create conditions for further development, working through and strengthening relations between children (Ciechomski 2018). Both in school and family life, the organisation of the upbringing environment to contribute to the development of empathic sensitivity is important. An open, friendly atmosphere, allowing the child to express their opinions and speak freely of their feelings and emotions, is one of the components of this environment. Moreover, many working methods with children exist, which aid the ability to name, recognise, express emotions, and shape the readiness to help others. These methods include working with literary texts, drama, training, inductive reasoning or art techniques, which - through play, action, creation or discussion - strengthen the skills of empathising, communication, creative thinking and open expression of feelings, experiences and knowledge of the surrounding world.

All activities of educational nature will contribute to the creation of personality potential in children, thus providing them with suitable tools. Equipped with such tools, they will be able to experience their self-agency and find joy and satisfaction in building empathic relations. Thanks to comprehensive actions that influence the whole community's life, the child can reach its full sensitivity (Ciechomski 2018).

Children brought up in the spirit of empathy have the courage to defend victims and are willing to display altruistic behaviours. Moreover, they are responsible for themselves and others, and they are not indifferent to anyone. The development of empathic sensitivity becomes particularly important in the context of various challenges and problems of the modern world, such as cultural and economic differences and the associated anti-social behaviours, for example, aggression (Davis 1994). 
FUNDING: This research received no external funding.

CONFLICT OF INTEREST: The author declares no conflict of interest.

\section{REFERENCES}

Altmann, Tobias \& Marcus Roth. 2013. "The evolution of empathy: from single components to process models." Pp. 171-187 in Handbook of Psychology of Emotions: Recent Theoretical Perspectives and Novel Empirical Findings. Volume 2, edited by C. Mohiyeddini, M. Eysenck, \& S. Bauer. New York: Nova Science Publishers.

Aronfreed, Justin M. 1970. "The socialization of altruistic and sympathetic behavior: Some theoretical and experimental analyses." Pp. 123-126 in Altruism and Helping Behavior: social psychological studies of some antecedents and consequences, edited by J. Macaulay, L. Berkowitz, \& J. Aronfreed. New York: Academic Press.

Baron-Cohen, Simon. 2014. Teoria zła. O empatii i genezie okrucieństwa. Sopot: Smak Słowa.

Barwiński, Marek. 2016. "Wielokulturowość we współczesnych polskich badaniach geograficznych i edukacji geograficznej - zarys problematyki.” Przegląd Geograficzny 88(2):137-158.

Białek, Kinga. 2015. Międzykulturowość w szkole. Poradnik dla nauczycieli i specjalistów. Warszawa: Ośrodek Rozwoju Edukacji.

Birch, Ann. 2005. Psychologia rozwojowa $w$ zarysie. Warszawa: Polskie Wydawnictwo Naukowe.

Bogucka, Maria \& Anna Turaj. 2004. “Wyrażanie przez dzieci własnych uczuć i emocji: wykorzystanie wybranych technik arteterapii.” Pp. 117-123 in Edukacja kulturalna w szkole, edited by K. Polak. Kraków: Wydawnictwo Uniwersytetu Jagiellońskiego.

Buksik, Dariusz. 1997. “Wybrane psychologiczne teorie rozwoju moralnego człowieka." Seminare. Poszukiwania naukowe 13:147-166.

Ciechomski, Maciej. 2018. “Rozwijanie empatii u dzieci w młodszym wieku.” Pp. 67-92 in Dzieci z trudnościami poznawczymi i emocjonalnymi w młodszym wieku, Terapia $i$ wspieranie, edited by Emilia Śmiechowska-Ptrovskij \& Elżbieta Kwiatkowska. Warszawa: Wydawnictwo Naukowe UKSW.

Czerniawska, Mirosława \& Emilia Dolata. 2005. “Osobowościowe uwarunkowania systemów wartości.” Psychologia rozwojowa 10(2):123-133.

Davis, Mark H. 1994. Empatia: O umiejętności współodczuwania. Gdańsk: Gdańskie Wydawnictwo Psychologiczne.

Davis, Mark H., Carol Luce, \& Stephen J. Kraus. 1994. "The heritability of characteristics associated with dispositional empathy.” Journal of Personality 62(3):369-391.

Feshbach, Norma D. \& Seymour Feshbach. 1969. "The relationship between empathy and aggression in two age groups.” Developmental Psychology 1(2):102-107.

Gulin, Wojciech. 1994. Empatia dzieci i młodzieży. Lublin: Towarzystwo Naukowe KUL. Gulin, Wojciech. 1997. "Theodora Lippsa psychologiczna koncepcja empatii." Forum 
Psychologiczne 2(1): 25-37.

Hoffman, Martin L. 2006. Empatia i rozwój moralny. Gdańsk: Gdańskie Wydawnictwo Pedagogiczne.

Kalliopuska, Mirja. 1992. Holistic Empathy Education among Preschool and School Children (http://files.eric.ed.gov/fulltext/ED348167.pdf).

Keysers, Christian. 2011. The Empathic Brain. Cambridge: Social Brain Press.

Klus-Stańska, Dorota \& Maria Szczepska-Pustkowska. 2009. Pedagogika wczesnoszkolna - dyskursy, problemy, rozwiązania. Warszawa: Wydawnictwa Akademickie i Profesjonalne.

Kliś, Maria. 2012. “Adaptacyjna rola empatii w różnych sytuacjach życiowych.” Horyzonty Psychologii II: 147-171.

Kwasek, Artur. 2018. “Wyzwania współczesnej edukacji w kontekście zmian technologicznych i społecznych.” Kwartalnik Naukowy Uczelni Vistula 2(56):203-216.

Łobocki, Mieczysław. 1998. Praca wychowawcza z dziećmi i młodzieża. Lublin: Wydawnictwo Uniwersytetu Marii Curie-Skłodowskiej.

Łobocki, Mieczysław. 2002. Wychowanie moralne w zarysie. Kraków: Oficyna Wydawnicza "Impuls."

Markowska-Manista, Urszula. 2014. “Projekt Bohaterskiej Wyobraźni (Heroic Imagination Project).” Parezja. Czasopismo Forum Młodych Pedagogów przy Komitecie Nauk Pedagogicznych PAN 2: 55-58.

Markowska-Manista, Urszula. 2016. "Walka ze stereotypami odmienności kulturowej -szkolne i pozaszkolne pola bitewne.” Pp. 315-339 in Twierdza. Szkoła w metaforze militarnej. Co w zamian?, edited by M. Dudzikowa and S. Jaskulska. Bydgoszcz: Wydawnictwo Uniwersytetu Kazimierza Wielkiego.

Markowska-Manista, Urszula. 2019. "Praca z bajką, baśnią, legendą - idea, metodyka, znaczenie.” Pp. 37-48 in Afrykańska układanka. Bajki legendy, opowieści afrykańskie w edukacji globalnej. Materiały dla nauczycieli i pedagogów, edited by B. Machul-Telus \& U. Markowska-Manista. Warszawa: Centrum Wielokulturowe.

Markowska-Manista, Urszula \& Barbara Pasamonik. 2017. "Wstęp: O kryzysie migracyjnym w perspektywie pedagogiczno-psychologicznej.” Pp. 7-14 in Kryzys migracyjny: perspektywa pedagogiczno-psychologiczna 2, edited by U. Markowska-Manista \& B. Pasamonik. Warszawa: Wydawnictwo Akademii Pedagogiki Specjalnej.

Markowska-Manista, Urszula \& Philip Zimbardo. 2014. "Projekt Bohaterskiej Wyobraźni Profesora Philipa Zimbardo a realia współczesnego kształcenia młodzieży.” Parezja. Czasopismo Forum Młodych Pedagogów przy Komitecie Nauk Pedagogicznych PAN 2: 59-78.

Minkiewicz-Najtkowska, Janina. 2003. Kompetencje wychowawcze nauczycieli. Wybrane zagadnienia. Poznań: WAE.

Morgan, Sharon R. 1983. "Development of Empathy in Emotionally Disturbed Children." Humanistic Education and Development. 1(4):13-21.

Olek-Redlarska, Zofia. 2015. "Rozumienie pojęć moralnych w wychowaniu moralnym dzieci młodszych. Empatia i motywacja do zachowań moralnych.” Rocznik Teologii Katolickiej XIV/2: 113-124.

Rembowski, Józef. 1989a. Empatia. Studium psychologiczne. Warszawa: PWN. 
Rembowski, Józef . 1989b. “Problematyka empatii w terapii.” Psychoterapia 3:73-82. Skorupka, Stanisław, Halina Audreska \& Zofia Łempicka. 1969. Mały słownik języka polskiego. Warszawa: PWN.

Skorupka, Alfred. 2019. “Czy empatia jest potrzebna w zarządzaniu?” Zeszyty Naukowe Wyższej Szkoły Zawodowej im. Witelona w Legnicy 32(3): 45-53.

Strumińska-Doktór, Anna. 2008. "Dylematy wychowania XXI wieku a rozwój zrównoważony.” Studia Ecologiae et Bioethicae 6: 359-369.

Szafrańska, Karina. 2016. "Kształtowanie empatii i uczuć moralnych u dzieci w wieku przedszkolnym metodami dramy." Edukacja Elementarna $w$ Teorii i Praktyce 3(41):255-266.

Szczepańska-Pabiszczak, Barbara. 2011. “Empatia jako forma komunikacji w świecie życia codziennego.” Studia Kulturoznawcze 1:69-78.

Tomczuk, Jolanta. 2004. "Związek empatii z doświadczeniem - narracyjne badania eksperymentalne.” Roczniki Psychologiczne VII(2):105-130.

Vasta, Ross, Marshall M. Haith \& Scott A. Miller. 1995. Psychologia dziecka. Warszawa: Wydawnictwa Szkolne i Pedagogiczne.

Więcławska, Anna. 2018. "Rodzice jako fundament rozwoju i wychowania dziecka ku dojrzałości.” Przegląd Krytyczny 1:46-47.

Wilczek-Różyczka, Ewa. 2002. Empatia i jej rozwój u osób pomagających. Kraków: Wydawnictwo Uniwersytetu Jagiellońskiego.

\section{BIOGRAPHICAL NOTE}

Sandra Kwaśniewska-Paszta, MA, is a Doctoral Candidate at the Faculty of Education, University of Warsaw. She is interested in education, schooling, childhood studies and children's rights issues.

OPEN ACCESS: This article is distributed under the terms of the Creative Commons Attribution Non-commercial License (CC BY-NC 4.0) which permits any non-commercial use, and reproduction in any medium, provided the original author(s) and source are credited. 